\title{
Distance Learning Approach in Interprofessional
}

\section{Higher Education}

\author{
Luísa Schubach da Costa Barreto ${ }^{1, *}$, Guido Artemio Marañón-Vásquez ${ }^{1}$, Rodrigo Lopes \\ de Lima $^{1}$, Ana Maria Bolognese ${ }^{1} \&$ Margareth Maria Gomes de Souza ${ }^{1}$ \\ ${ }^{1}$ School of Dentistry, Pediatric Dentistry and Orthodontics Department, Federal University of \\ Rio de Janeiro, UFRJ, Rio de Janeiro, 21941-617, Brazil \\ *Corresponding author: School of Dentistry, Pediatric Dentistry and Orthodontics Department, \\ Federal University of Rio de Janeiro, UFRJ, 325 Professor Rodolpho Paulo Rocco, Cidade \\ Universitária, Ilha, do Fundão, Rio de Janeiro, 21941-617, Brazil. Tel: 55-21-3938-2015. E- \\ mail: luisaschubach@gmail.com
}

Received: October 13, 2020 Accepted: December 17, 2020 Published: December 20, 2020

doi:10.5296/ije.v12i4.17821 URL: https://doi.org/10.5296/ije.v12i4.17821

\begin{abstract}
Literature seeks to provide a new methodological education approach in health professions, but none consider evaluate student's ideal preferences. The aim of this study is to understand what the preferences of distance learning in higher education are. The study has assessed online resources, the primary objective was to provide information about the types of teaching tools. The secondary objective was to integrate technological advances in the Medical School of Speech Therapy. The outcomes have been further discussed under measurements of an observational protocol, testing the effectiveness of these resources on the qualifications of undergraduate Orthodontics students at Federal University of Rio de Janeiro. Summarizing the preferences, an online form was applied in Brazilian Institutions. Based on the 533 evaluations, a distance learning platform was developed to assist the daily study process, containing educational videos, a discussion forum, questionnaires for the increased learning activity, and individual feedback reports. Overall, 88 undergraduate Speech Therapy students at Federal University of Rio de Janeiro were recruited, eventually, 34 fully participated. They were randomly allocated into two groups to perform a face-to-face test: (A) without and (B) with access to the platform. The data were analyzed using the t-test, Chi-square, and Fisher's exact test. The parameter of educational videos had the highest frequency of all responses. After the interactive experience of a platform, group B had a higher average (6.45) beyond group A (5.44). At the end of the research, it was possible to state that the distance learning approach was effective as a method to enhance teaching and gain technological knowledge.
\end{abstract}

Keywords: interprofessional relations, distance education, educational technology, teaching, speech therapy 


\section{Introduction}

\subsection{About Orthodontics Course}

The Orthodontics course is offered in undergraduate Speech Therapy Brazilian Institutions and there is a significant interrelation between these two major areas (Amaral et al., 2006). Speech therapy is part of Medical School at Federal University of Rio de Janeiro since 1995 and it is a great ally of Orthodontics, an interprofessional education very dependent. Additionally, there is a consensus in the literature (Amaral et al., 2006, Cohen et al., 2003, Figueiredo et al., 2018, Silva \& Canto., 2014) of reported multidisciplinary cases in which functional speech restoration was obtained only after orthodontic correction and also, orthodontic stability was only reached after functional re-establishment of communication.

\subsection{Challenges in Education Field}

Currently, public and private Institutions have big challenges to face in the field of knowledge, the quarantine in Brazil started on March 13th at Federal University of Rio de Janeiro and physical classes are forbidden, teachers assume multiple tasks, and impediments of distance learning are present (Chavarría-Bolaños et al., 2020). Education tries to overcome the COVID19 pandemic combined with technologies, dated for decades as an important contribution (Schönwetter et al., 2010, Blue \& Henson, 2015, Huang et al., 2014, Cook et al., 2010), such as the development of virtual platforms as an approach of distance learning (Lima et al., 2019).

Regarding student performance (Will, 2015, Barreto et al., 2020, Brumini et al., 2014), one type of online resource that can be cited for assessing the learning process is the use of forms. The results are presented in quantitative analyzes that can direct the goals to solve problems and enhance teaching through those platforms (Zlatkin-Troitschanskaia \& Shavelson, 2019, Schönwetter et al., 2016).

\subsection{Technological Advances in Learning Process}

The use of computers in study (Buchanan, 2001, McCann et al., 2010, Rosenberg et al., 2003, Marsh et al., 2001, Luffingham, 1984) was evidenced positively in the literature, including feedback reports of increased motivation to learn (Cook \& Artino, 2016). It is possible to assess the subjects available online whenever necessary and at any time (Turner \& Weerakone, 1993, Rao et al., 2020, Ulkur et al., 2015). One only computer or a cellphone with Internet access would be enough, however, this ideal is actually hard to imagine in Brazilian Institutions. According to a continuous national household sample survey published in (Instituto Brasileiro de Geografia e Estatística [IBGE], 2018), one in four Brazilians have Internet access, consequently, 46 million people don't have proper access to a regular network. Likewise, there is insufficient scientific evidence regarding the effective replacement of the conventional way of teaching when compared to online resources (Ireland et al., 2012, Kunin et al., 2014, Iftakhar, 2016). Thus, it can be considered that technology advances combined with traditional methods, towards online instructions to enhance teaching, can encourage attitudes (Chadwick et al., 2002, Cook, 2014, Moore, 1976) to improve students' study despite low economics ratings.

Both the quality of the teacher and the effectiveness of the resources are closely related (Zlatkin-Troitschanskaia \& Shavelson, 2019, Luffingham, 1984, Zimmerman, 2012). In addition, the development of new teaching tools and online resources for teaching and learning should be integrated with existing distance learning platforms to improve the workflow of teachers and increase student's performance in subjects and consequently, reduce difficulties during interprofessional education (Olson \& Bialocerkowski, 2014). In a simple way, with the 
favorable use of cell phones or computers (Cohen et al., 2003, Blue \& Henson, 2015, Cook et al., 2010), it may be possible to create a smart learning environment with Internet access that brings together teaching tools for increase learning activity despite the pandemic situation (Chavarría-Bolaños et al., 2020) to didactically compile subjects.

However, both private and public institutions should establish training space for technologyassisted (Rosenberg et al., 2003, Marsh et al., 2001) resources keeping in mind that, not all students are prepared and aware of the use of those applications. Still, not all professors (Machtmes \& Asher, 2000, Diener \& Dweck, 1978) have the online teaching experience and it should be improved for cases such as quarantine, where physical classes are forbidden. Online instructions could overcome those impediments (Hughes et al., 2008, Zimmerman, 2012) with courses to gain technological knowledge.

As the Medical School at Federal University of Rio de Janeiro has a smart learning environment in their libraries with Internet access and computers, the present study aimed to (1) obtains information about preferences of teaching tools through online forms sent to Speech Therapy professionals and undergraduate Dentistry and Speech Therapy students from Brazilian educational Institutions, and (2) test the effectiveness of an interactive distance learning platform on the qualifications of enrolled students in Medical School of Speech, Language and Hearing Sciences at Federal University of Rio de Janeiro.

\section{Method}

\subsection{Institutional Review Board Approval}

The research protocol of the present study was initially submitted to the Research Ethics Committee of the Faculty of Dentistry of Federal University of Rio de Janeiro (project approved by the ethics committee (number: 3.347.899, 22/09/2018 - School of Dentistry / UFRJ). The volunteers agreed to participate in the study by signing the Free and Informed Consent Form. Number CAAE 95467018.5.0000.5257.

\subsection{Interprofessional Education}

Initially, as Orthodontics is part of the undergraduate Dentistry and Speech Therapy curriculum in public and private Brazilian educational Institutions, preliminary research was carried out to assess preferences in the use of online teaching tools. Individual anonymous forms (Figure 1) were developed and send by e-mail for undergraduate students in Dentistry and Speech Therapy from public and private institutions in Brazil and Speech Therapy professionals were also contacted through disclosure on social media.

A virtual platform named Survey Monkey® (https://pt.surveymonkey.com) garners the online forms, containing questions with multiple choice answers on the following subjects: frequency of using a computer to study, previous use of online courses, the experience of a distance learning platform, and preferences for different teaching tools available. 
1. What is your academic level? (Multiple choice)

A) Undergraduate Speech Therapy student

B) Undergraduate Dentistry student.

C) Speech Therapy professional.

2. Write the institution that currently holds or completed your graduation.

3. Do you use computer for study? (Multiple choice)

A) Only when class is available online.

B) Never use computer for study.

C) Yes, frequently.

D) Yes, rarely.

4. Do you use online courses? (Multiple choice)

A) Yes, I really like them.

B) Yes but I didn't like the experience.

C) I never used.

5. Have you ever experienced a distance learning platform? (Multiple

choice)

A) Yes.

C) I don't know what it is

6. In your opinion, what would be the best teaching tool for use on distance

learning plataform? (You can select more than one option)

A) Slides with theoretical content;

B) Articles, news and reports related;

C) Book references;

E) Educational videos;

F) Others (please, list here)

Figure 1. Schematic Representation of the Questions Included in the Online Form to Provide Information about the Types of Teaching Tools

\subsection{Development of Interactive Platform}

Therefore, based on the information retrieved on the forms, the teaching tools were developed and combined in a distance learning platform, a new approach for the course to connect teacher's knowledge and student's preferences on interprofessional higher education. All the online resources reported were considered such as educational videos, discussion forums, questionnaires for the increased learning activity, and individual feedback reports. Consequently, an interactive distance learning platform was available in the year 2019 for undergraduate Speech Therapy students enrolled in the Orthodontics course at Federal University of Rio de Janeiro.

The distance learning platform was hosted for free and with a particular code to login in to a website named Udemy ${ }^{\circledR}$ (https://www.udemy.com), considered only as supplementary material, a reinforcement for the theoretical content of the course, and never its replacement of physical classes. A total of 13 class sections were made, in each one, educational videos were developed by the researchers under the guidance of professors in Orthodontics at Federal University of Rio de Janeiro (M.M.G.S, R.L.L and A.B.). Each class section available on the platform contained: (1) educational videos of up to fifteen minutes each (two videos per section as a minimum); (2) recommended bibliographic references on the subject; (3) questionnaires to increase learning activity; and (4) discussion forum to solve possible doubts and chat with the tutor responsible for managing the platform (resident in Orthodontics as an online teacher; L.S.C.B. supervised by M.M.G.S.).

In the end, the student could evaluate himself after completed each class section, individual feedback reports (Figure 2) were created as an optional resource to expose suggestions and comments about the subject studied on the distance learning platform, these reports were hosted for free on the website named Typeform ${ }^{\circledR}$ (https://www.typeform.com). 
1) Was it easy to understand the subject during this class section? Evaluate from 0 to 10 , with 10 being the maximum value assigned for full understanding of the exposed subject, and 0 the value referring to non-understanding and difficulty learning of the subject.

$$
\begin{aligned}
& \begin{array}{|c|c|c|c|c|c|c|c|c|c|c|}
\hline 0 & 1 & 2 & 3 & 4 & 5 & 6 & 7 & 8 & 9 & 10 \\
\hline \text { Lowest score }
\end{array} \\
& \hline
\end{aligned}
$$

2) Were the teacher's explanations during this class section clear? Evaluate from 0 to 10 , with 10 being the maximum value attributed for total clarity during the teacher's explanations, and 0 the value referring to the difficulty of understanding the teacher's explanations.

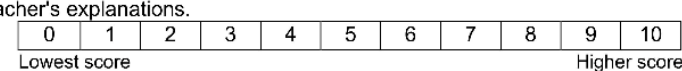

3) Was the content of this class section relevant? Evaluate from 0 to 10 , with 10 being the maximum value assigned for high relevance of the content, and 0 the value being the maximum value assigned for high relevance of the content,
referring to low relevance and not usefulness of the exposed content. \begin{tabular}{|c|c|c|c|c|c|c|c|c|c|c|}
\hline & referring to low relevance and not usefulness of the exposed content. \\
\hline 0 & 1 & 2 & 3 & 4 & 5 & 6 & 7 & 8 & 9 & 10 \\
\hline
\end{tabular} \begin{tabular}{|c|c|c|c|c|c|c|c|c|c|c|}
\hline 0 & 1 & 2 & 3 & 4 & 5 & 6 & 7 & 8 & 9 & 10 \\
\hline
\end{tabular}

4) Select the grade you would give for this class section. Evaluate from 0 to 10 , with 10 being the maximum value assigned for an excellent class section, and 0 the value referring to a deficient class section.

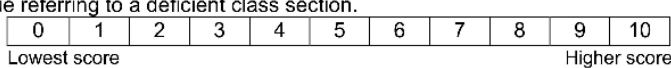

5) Thank you. Would you like to add something to this class section?

Figure 2. Schematic Representation of the Questions Included in the Individual Feedback Reports in Each Class Section Available on the Interactive Distance Learning Platform

\subsubsection{An Observational Example: Distance Learning}

The outcomes have been further discussed under measurements and all the technological advances already reported were integrated with the Medical School of Speech, Language, and Hearing Sciences at Federal University of Rio de Janeiro. One class section was chosen (developed by R.L.L.) looking forward to testing the effectiveness of the distance learning platform (pilot study) in a face-to-face test which qualification could be from 0 to 10 points. Recruitment of 88 undergraduate Speech Therapy students from Federal University of Rio de Janeiro enrolled in Orthodontics course in 2019 were eligible for this observational example, illustrated in the flowchart (Figure 3).

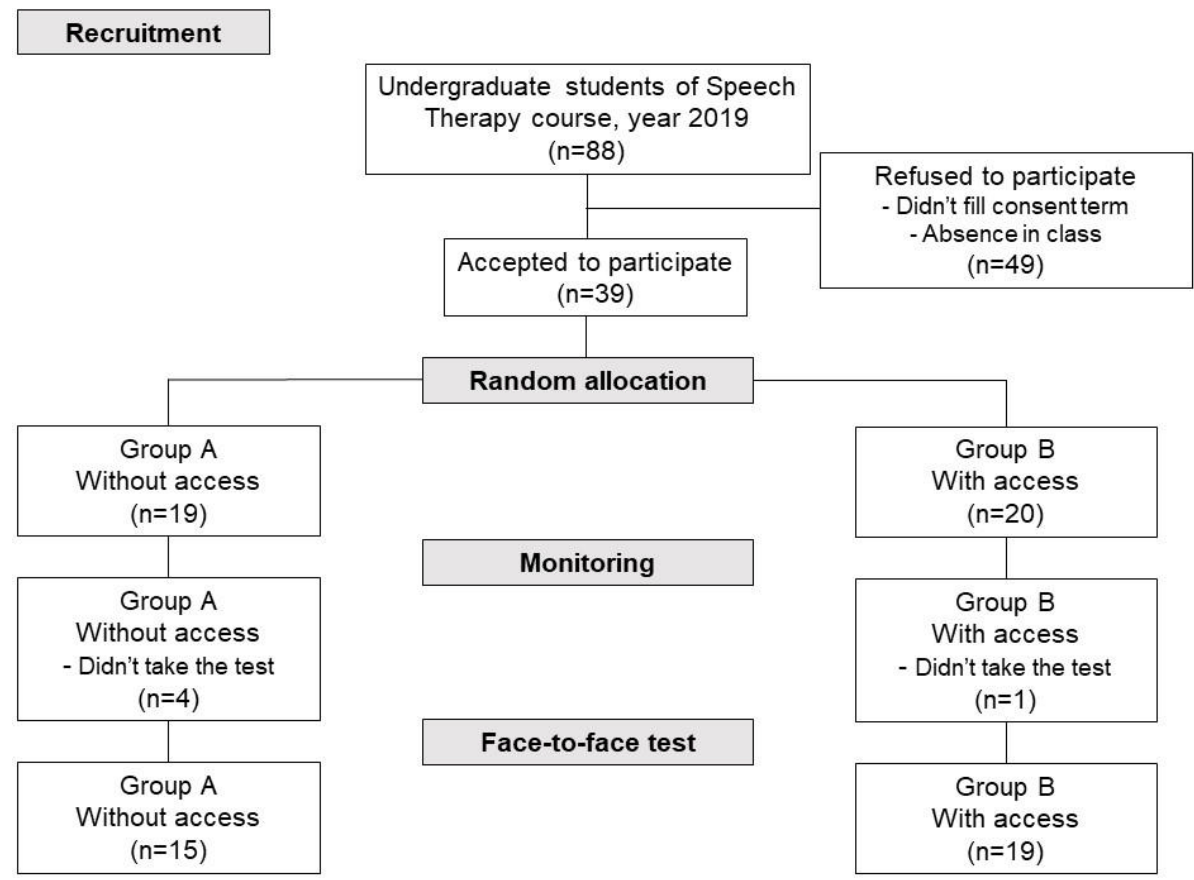

Figure 3. Flowchart of Student Monitoring during the Assessment of the Effectiveness of the Distance Learning Platform 
Students who agreed to participate and signed the Free and Informed Consent Form were randomly allocated into two groups: (A) without access and (B) with access to the distance learning platform. The randomization process was carried out on the Graphpad ${ }^{\circledR}$ website (https://www.graphpad.com/quickcalcs/randomize1).

The two randomly selected groups were: participants of Group A (without access) which only studied for the test with the subject presented in physical class and participants of Group B (with access) who received a personal password and guide with access to distance learning platform. The use of the platform was confirmed by the percentage of viewing the class section, illustrated by the Udemy ${ }^{\circledR}$ website. The participation included the following criteria: undergraduate Speech Therapy students from Federal University of Rio de Janeiro enrolled in Orthodontics course in 2019, presence in the physical class, the signature of the Free and Informed Consent Form, reached a percentage of viewing the class section (35\% of the content available for Group B) and presence in the face-to-face test applied 15 days after the class. The evaluations were carried out by the responsible researcher (L.S.C.B.).

\subsubsection{Statistical Analysis}

Using a formula to compare two means (Pocock, 1983), a sample size calculation was performed to detect the minimum difference between the qualifications of students with and without access to the platform (pilot study). Considering as parameters the power of $80 \%$, a significance level of 5\%, and assuming the standard deviation of 0.4 ; a total of 20 subjects (10 per group) were required as a minimum for the observational example.

All analyzes were made by two researchers (L.S.C.B and G.A.M.V) and performed using twotailed tests and a 5\% significance level in the SPSS v21 program (IBM Corp., Armonk, NY, USA). The Chi-Square and Fisher's exact tests were used to assess differences in the frequency of computer use, previous use of online courses, the experience of a distance learning platform, and their academic level including the origin of an educational institution (public or private). The frequencies about the preferences for different teaching tools available, issued by the participants, were presented in a vertical bar graph (Graphic generated in GraphPad Prism GraphPad Software, San Diego, CA, USA). On the other hand, the averages of the qualifications of the groups without (A) and with (B) access to the distance learning platform were compared using the unpaired t-test.

\section{Results}

\subsection{Recruitment}

A total of 533 evaluations (128 from Speech Therapy professionals, 181 from undergraduate Dentistry students, and 224 from undergraduate Speech Therapy students) responded to the online form about their preferences in the use of types of online teaching tools. Of the participants in the field of Speech Therapy, 287 belonged to public Institutions, while 65 were from private Institutions.

\subsection{Data Analysis}

According to the academic level of the research participants, the group of undergraduate Speech Therapy students was used as a reference since this will be the group to test the effectiveness of the distance learning platform on the observational example developed based on the results obtained in the form. 


\section{Macrothink Institute ${ }^{T M}$}

Considering the institution's origin of the participants, there was no association between the frequency of using the computer as a teaching tool and academic level ( $\mathrm{p}>0.05)$, Table 1.

Table 1. Use of Computer for Study

\begin{tabular}{|c|c|c|c|}
\hline & $\begin{array}{l}\text { Frequently } \\
\text { n }(\%)\end{array}$ & $\begin{array}{l}\text { Rarely / Never } \\
\text { n (\%) }\end{array}$ & $p$ value \\
\hline Speech Therapy students & $191(85.3)$ & $33(14.7)$ & Reference \\
\hline Dentistry students & $141(77.9)$ & $40(22.1)$ & 0.068 \\
\hline Speech therapy professionals & $105(82.0)$ & $23(18.0)$ & 0.451 \\
\hline $\begin{array}{l}\text { Speech Therapy students and } \\
\text { professionals (Public Institution) }\end{array}$ & $246(85.7)$ & $41(14.3)$ & 0.091 \\
\hline $\begin{array}{l}\text { Speech Therapy students and } \\
\text { professionals (Private Institution) }\end{array}$ & $50(76.9)$ & $15(23.1)$ & \\
\hline
\end{tabular}

Data are presented as frequencies and percentages, $\mathrm{n}(\%)$.

* Indicates statistically significant association (Fischer exact test; $\mathrm{p} \leq 0.05$ ).

On the other hand, there was a difference in the frequency of use of online courses between undergraduate students and professionals in Speech Therapy $(\mathrm{p}<0.001)$, Table 2. Fifty percent of undergraduate Speech Therapy students never took courses online, while $62 \%$ of Speech Therapy professionals had already done and enjoyed this technological feature. Similarly, there was a difference in the frequency of use of courses depending on the institution of origin $(\mathrm{p}<0.001)$, Table 2 .

Table 2. Use of Online Courses

\begin{tabular}{lcccc}
\hline & $\begin{array}{c}\text { Yes, I really } \\
\text { like them } \\
\mathrm{n}(\%)\end{array}$ & $\begin{array}{c}\text { Yes, but I didn't } \\
\text { like the } \\
\text { experience } \mathrm{n}(\%)\end{array}$ & $\begin{array}{c}\text { I never used } \\
\mathrm{n}(\%)\end{array}$ & $p$ value \\
\hline Speech Therapy students & $77(34.4)$ & $34(15.2)$ & $113(50.4)$ & $\begin{array}{c}\text { Reference } \\
\text { Dentistry students }\end{array}$ \\
$\begin{array}{l}\text { Speech therapy professionals } \\
\text { Speech Therapy students and professionals }\end{array}$ & $79(38.3)$ & $18(10.0)$ & $93(51.7)$ & 0.281 \\
$\begin{array}{l}\text { (Public Institution) } \\
\begin{array}{l}\text { Speech Therapy students and professionals } \\
\text { (Private Institution) }\end{array}\end{array}$ & $113(39.4)$ & $52(18.1)$ & $19(14.8)$ & $<0.001^{*}$ \\
\hline
\end{tabular}

Data are presented as frequencies and percentages, $\mathrm{n}(\%)$.

* Indicates statistically significant association (Chi-square test; $\mathrm{p} \leq 0.05$ ).

Participants from private Institutions showed a higher frequency of taking courses online than those from public Institutions. The associations between distributions according to the previous use of the distance learning platform and the academic level or institution of origin of the participants were not observed ( $\mathrm{p}>0.05)$, Table 3 . 
Table 3. Experience of Distance Learning Platform

\begin{tabular}{lcccc}
\hline & Yes & No & I don't know what it is & $p$ value \\
& $\mathrm{n}(\%)$ & $\mathrm{n}(\%)$ & $\mathrm{n}(\%)$ & \\
\hline Speech Therapy students & $175(78.1)$ & $14(6.3)$ & $35(15.6)$ & Reference \\
$\begin{array}{l}\text { Dentistry students } \\
\text { Speech therapy professionals }\end{array}$ & $94(73.4)$ & $20(11.0)$ & $31(17.1)$ & 0.181 \\
$\begin{array}{l}\text { Speech Therapy students and } \\
\text { professionals (Public Institution) }\end{array}$ & $223(77.7)$ & $18(7.0)$ & $25(19.5)$ & 0.595 \\
$\begin{array}{l}\text { Speech Therapy students and } \\
\text { professionals (Private Institution) }\end{array}$ & $46(69.7)$ & $5(7.6)$ & $46(16.0)$ & 0.371 \\
\hline
\end{tabular}

Data are presented as frequencies and percentages, $\mathrm{n}(\%)$.

* Indicates statistically significant association (Chi-square test; $\mathrm{p} \leq 0.05$ ).

Regarding the preferences of participants about types of teaching tools, the parameter of educational videos was the most chosen by all groups (Figure 4). Both in the group of undergraduate Speech Therapy students and undergraduate Dentistry students, the second most chosen resource was the inclusion of questionnaires to increase learning activity. In the group of Speech Therapy professionals, the second most chosen parameter was the additional slides with theoretical content.

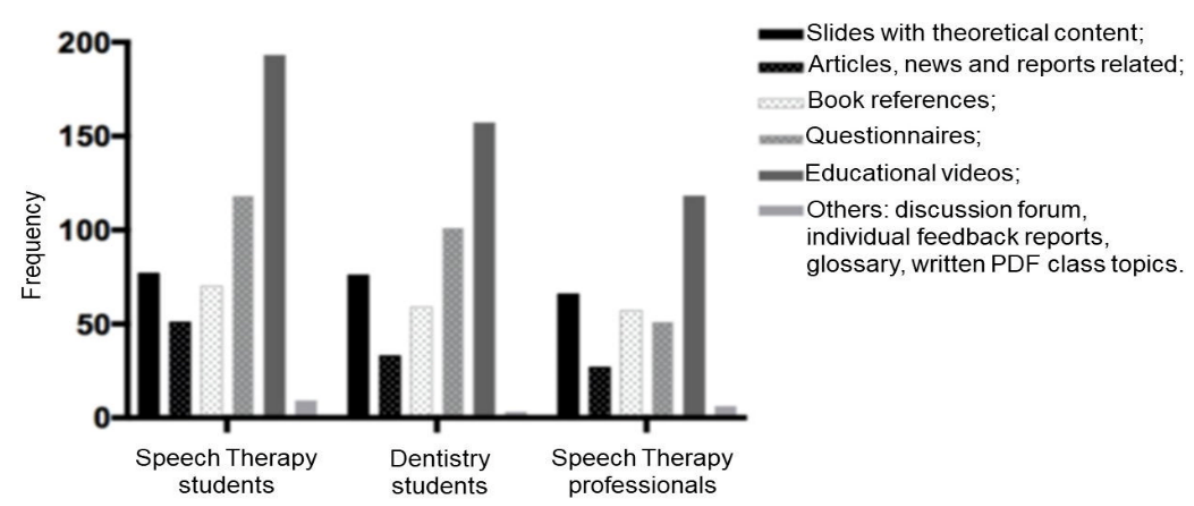

Figure 4. Absolute Frequencies of the Participants' Preferences of Distance Learning in Higher Education. (Graphic generated in GraphPad Prism - GraphPad Software, San Diego,

$$
\text { CA, USA) }
$$

Considering the observational protocol, 39 students of the Orthodontics course agreed to participate in the evaluation phase of the distance learning platform developed. Eventually, 34 fully participated, considering excluded those participants who not filled the consent form, didn't reach the percentage of viewing the class section (for Group B), and were absent in the physical class and/or absent in the face-to-face test. At least, 19 and 20 participants started in groups A and B, respectively; however, 5 did not complete it. All participants in group B accessed more than $35 \%$ of the content available on the platform, showing interest in the distance learning platform, the only one excluded didn't take the test. The group that had access to the platform had a higher average qualification than the group that did not have access to it (average difference $=1.1)$; however, this difference was not statistically significant $(p>0.05)$, Table 4. 
Table 4. Comparison of Face-to-Face Test Scores Regarding access to the Distance Learning Platform

\begin{tabular}{cccc}
\hline & $\begin{array}{c}\text { Group A } \\
\text { Without access }\end{array}$ & $\begin{array}{c}\text { Group B } \\
\text { With access }\end{array}$ & $p$ value* \\
\hline $\mathrm{N}$ & 15 & 19 & 0.292 \\
average (SD) & $5.44(2.61)$ & $6.45(2.82)$ & \\
ICC 95\% & $(4.00-6.89)$ & $(5.09-7.81)$ & \\
\hline
\end{tabular}

* Unpaired t-test. SD - standard deviation, ICC - confidence interval.

\section{Discussion}

For decades (Schönwetter et al., 2016, Buchanan, 2001, McCann et al., 2010, Rosenberg et al., 2003, Marsh et al., 2001), literature seeks to provide a new methodological education approach in health professions, but none consider evaluate student's ideal preferences (Barreto et al., 2020). This study aims to understand what are the preferences of distance learning in higher education. The study has assessed online resources for two objectives, the primary objective was to provide information about the types of teaching tools. After the results, it was possible to evaluate the frequency, statistically significant, concerning the use of computers for study, conducting courses on websites, and using the teaching platform.

The educational institution of origin, corresponding to the academic level, was the dividing factor among the participants in this research. A smart learning environment in federal universities should be mandatory to overcome impediments in higher education, in which Internet access and computers should be widely available. Studies (Brumini et al., 2014, Zlatkin-Troitschanskaia \& Shavelson, 2019) reported differences concerning infrastructure, private Institutions have good physical facilities and resources for teaching, consider as a relevant factor that students can face inequalities in public Institutions.

Coombs (1969), defined education as a set of two essential factors being defined as an entrance and an exit door. According to him, the components that compromise the interrelation of teacher and student and the resources that could increase teaching and learning are, respectively, the objectives and results of the educational process during medical education researches (Bunniss \& Kelly, 2010). Thus, to stimulate the best performance of students (O'Brien, 1997), change their attitudes (Kharbanda, 2006) and also, increase learning activity (Machetes \& Asher, 2000), it is necessary to develop their personal maturity. The encouragement of learning by the teacher is important (Diener \& Dweck, 1978, Hughes et al., 2008, Del Prette et al., 1998) as long as the student is willing to acquire knowledge in all areas of his education.

The creation of smart learning environments can assist the teaching process through the use of technological advances (Rosenberg et al., 2003, Marsh et al., 2001, Luffingham, 1984, Chadwick et al., 2002) centralized in the individual development of the student. It can be explained because learning is considered an individual activity, and each one has a particular way of acquiring knowledge. The author William Glasser (1988) reported that images and sounds (what is seen and heard) are responsible for $50 \%$ of our learning (Kianipour \& Hoseini, 2012). Thus, as shown in the present study, the most chosen parameter (Figure 4) was educational videos which can enhance learning and facilitate content retention, since students can watch at any time and as many times as necessary.

Undergraduate Speech Therapy students were the group that obtained the greatest access to the 


\section{MInstitute Macrothink}

Internet, with high frequencies in comparison with undergraduate Dentistry students and Speech Therapy professionals at private Institutions. It was seen that undergraduate Speech Therapy students showed greater access to the computer for study $(85.3 \%)$, (Table 1) and greater use of the distance learning platform (78.1\%), (Table 3). On the other hand, when asked about enrolling in online courses (Table 2), this group had a lower frequency $(34.4 \%)$ when compared to Speech Therapy professionals $(61.7 \%)$. This shows a constant search for updating the knowledge of Speech Therapy professionals even after graduation and, eventually, not leave aside the continuing education on interactive distance learning platforms.

The secondary objective was to integrate technological advances in the Medical School of Speech, Language, and Hearing Sciences at Federal University of Rio de Janeiro. As a result of a meta-analysis (Machtmes \& Asher, 2000), technological advances offer the creation and incorporation of several online teaching tools, aiming to offer an interactive environment for the transmission of adequate knowledge.

Different researchers (Diener \& Dweck, 1978, Hughes et al., 2008) already tested students' academic skills and reported an association between poor grades, low effort, and little incentive, resulting in academic performance failure. These results are similar to the present study, after encouraging an online teaching tool as support, difficulties encountered during the study were highlighted, students who did not have access to the distance learning platform obtained worse grades than the group with access (Table 4).

According to the observational example, a big loss of the initial sample size (Figure 3) was a limitation for the research. Overall, 88 students were recruited, only 34 fully participated and took the face-to-face test. This obtained non-statistically significant results. The absence of the student in the classroom negatively affects the final academic performance, because in the physical class the teacher can interact directly and promote debates (O'Brien, 1997, Del Prette et al., 1998, Will, 2015). During the pandemic situation (Barreto et al., 2020), in the class of 2020 was observed that $100 \%$ of all students enrolled in 2020 finished the 13 class sections available in the distance learning platform developed. However, it is still possible to say that the platform is effective in the teaching-learning process because the average for group B (with access) was slightly higher (6.45) compared to the average (5.44) for group A (without access) during the observational example.

Hopefully, this research will encourage a team of teachers to develop and apply new methods incorporating different types of online resources. Incorporate technological advances through online teaching tools allow the breakdown of barriers between teacher and student. Thereby, it should also consider the students regarding their individual needs and ask about their difficulties encountered during the process of learning, to effectively improve the performance of both teacher and student and, consequently, the interprofessional educational process on a distance learning approach.

At the end of the research, it was possible to state that the distance learning approach was effective as a method to enhance teaching and gain technological knowledge. Overall, technological advances in the Medical School of Speech, Language, and Hearing Sciences can reduce the difficulties encountered during the learning of interprofessional higher education.

The incorporation of an online platform as a distance learning method approach was effective in this group of students. In the 2020 pandemic situation and absence of school classes, this knowledge was easily spread due to internet access on computers and mobile devices, increasing connection between teacher-student through the use of technology. Furthermore, it's recommended to new researchers re-test and improve online teaching tools during the next 


\section{Macrothink}

years, as a supplementary appliance for the education process.

\section{Acknowledgments}

The authors acknowledge the help received from all volunteers and the participation of undergraduate students in Dentistry and Speech Therapy at Federal University of Rio de Janeiro. This manuscript was based on a thesis submitted by the first author in partial fulfillment of the requirements for the master's degree in Orthodontics. The first author thanks the Brazilian Federal Agency for support and evaluation of Higher Education for the scholarship. L.S.C.B. appreciate the scholarship granted by the CAPES "This study was financed in part by the Coordenação de Aperfeiçoamento de Pessoal de Nível Superior - Brasil (CAPES). Finance Code 001". All authors gave their final approval and agree to be accountable for all aspects of the work.

\section{References}

Amaral, E. C. et al. (2006). Inter-relação entre a Odontologia e a Fonoaudiologia na motricidade orofacial. Revista CEFAC, 8(3), 337-351.

Barreto, L. S. C., Marañón-Vásquez, G. A., Lima, R. L., Bolognese, A., \& De Souza, M. M. G. (2020). Percepção dos Alunos sobre a Disciplina de Ortodontia durante a Graduação em Fonoaudiologia. Comunicação Científica e Técnica em Odontologia, 5(13), 156-166. https://doi.org/10.22533/at.ed.62220240113

Blue, C., \& Henson, H. (2015). Millennials and dental education: Utilizing educational Technology for Effective Teaching. Journal of dental hygiene, 89(1), 46-47.

Brumini, G., Špalj, S., Mavrinac, M., Biočina-Lukenda, D., Strujić, M., \& Brumini, M. (2014). Attitudes towards e-learning amongst dental students at the universities in Croatia. European Journal of Dental Education, 18, 15-23. https://doi.org/10.1111/eje.12068

Buchanan, J. A. (2001). Use of simulation technology in dental education. Journal of dental education, 65(11), 1225-1231.

Bunniss, S., \& Kelly, D. R. (2010). Research paradigms in medical education research. Medical Education, 44(4), 358-366. https://doi.org/10.1111/j.1365-2923.2009.03611.x

Chadwick, S. M., Bearn, D. R., Jack, A. C., \& O’Brien, K. D. (2002). Orthodontic undergraduate education: Developments in a modern curriculum. European Journal of Dental Education, 6(2), 57-63. https://doi.org/10.1034/j.1600-0579.2002.60203.x

Chavarría-Bolaños, D., Gómez-Fernández, A., Dittel-Jiménez, C., \& Montero-Aguilar, M. (2020). E-Learning in Dental Schools in the Times of COVID-19: A Review and Analysis of an Educational Resource in Times of the COVID-19 Pandemic. Odovtos-International Journal of Dental Sciences, 22(3), 69-86. https://doi.org/10.15517/ijds.2020.41813

Cohen, H. B., Walker, S. R., Tenenbaum, H. C., \& Spero, L. (2003). Interdisciplinary, webbased, self-study, interactive programs in the dental undergraduate program: A pilot. Journal of Dental Education, 67(6), 661-667. https://doi.org/10.1002/j.00220337.2003.67.6.tb03666.x

Cook, D. A., Levinson, A. J., \& Garside, S. (2010). Time and Learning Efficiency in Internet- 
Based Learning: A Systematic Review and Meta-Analysis. Advances in Health Sciences Education, 15(5), 755-770.

Cook, D. A., \& Artino, A. R. Jr. (2016). Motivation to learn: an overview of contemporary theories. Medical Education, 50(10), 997-1014. https://doi.org/10.1111/medu.13074

Cook, D. A. (2014). How much evidence does it take? A cumulative meta-analysis of outcomes of simulation-based education. Medical Education, 48(8), 750-760. https://doi.org/10.1111/medu.12473

Coombs, P. H. (1969). The world educational crisis. A systems analysis. British Journal of Educational Studies, 17(3), 333. https://doi.org/10.2307/3119654

Del Prette, Z. A. et al. (1998). Habilidades sociais do professor em sala de aula: um estudo de caso. Psicologia: Reflexão e Crítica, 11(3), 591-603. https://doi.org/10.1590/S010279721998000300016

Diener, C. I., \& Dweck, C. S. (1978). An analysis of learned helplessness: Continuous changes in performance, strategy, and achievement cognitions following failure. Journal of personality and social psychology, 36(5), 451-462. https://doi.org/10.1037/00223514.36.5.451

Figueiredo, R. F. et al. (2018). Relação interdisciplinar entre ortodontia e a fonoaudiologia. REVISTA FAIPE, 8(1), 85-100.

Huang, K. L., Chen, K, H., \& Ho, C. H. (2014). Enhancing Learning Outcomes through New E-Textbooks: A Desirable Combination of Presentation Methods and Concept Maps. Australasian Journal of Educational Technology, 30(5), 600-618. https://doi.org/10.14742/ajet.538

Hughes, J. N., Luo, W., Kwok, O. M., \& Loyd, L. K. (2008). Teacher-Student Support, Effortful Engagement, and Achievement: A 3-Year Longitudinal Study. Journal of Educational Psychology, 100(1), 1-14. https://doi.org/10.1037/0022-0663.100.1.1

Iftakhar, S. (2016). Google classroom: what works and how? Journal of Education and Social Sciences, 3(1), 12-18.

INTITUTO BRASILEIRO DE GEOGRAFIA E ESTATÍSTICA (IBGE) Brasília. (2018). Retrieved from https://biblioteca.ibge.gov.br/index.php/bibliotecacatalogo? view $=$ detalhes\&id $=2101705$

Ireland, A. J., Atack, N. E., \& Sandy, J. R. (2012). Experiences of wiki topic teaching in postgraduate orthodontics: What do the learners think? European Journal of Dental Education, 17(1), e109-e113. https://doi.org/10.1111/j.1600-0579.2012.00769.x

Kharbanda, O. P. (2006). Global issues with orthodontic education: a personal viewpoint. Journal of Orthodontics, 33(4), 237-240. https://doi.org/10.1179/14653205225021708

Kianipour, O., \& Hoseini, B. (2012). Effectiveness of training the choice theory of Glasser to teachers on improvement of students 'academic qualification. Journal of Educational and Instructional Studies in the World, 2(2), 117-123.

Kunin, M., Julliard, K. N., \& Rodriguez, T. E. (2014). Comparing face-to-face, synchronous, and asynchronous learning: postgraduate dental resident preferences. Journal of Dental Education, 78(6), 856-866. PMID: 24882771.

Lima, M. S. et al. (2019). Effectiveness of the Distance Learning Strategy Applied to 
Orthodontics Education: A Systematic Literature Review. Telemedicine and e-Health, 25(12), 1134-1143. https://doi.org/10.1089/tmj.2018.0286

Luffingham, J. K. (1984). An assessment of computer-assisted learning in orthodontics. British Journal of Orthodontics, 11(4), 205-208. https://doi.org/10.1179/bjo.11.4.205

Machtmes, K., \& Asher, J. W. (2000). A meta-analysis of the effectiveness of telecourses in distance education. American Journal of Distance Education, 14(1), 27-46. https://doi.org/10.1080/08923640009527043

Marsh, C. M., Hannum, W. H., Trotman, C. A., \& Proffit, W. R. (2001). Design and effectiveness of a computer-based continuing education program for orthodontists. The Angle Orthodontist, 71(1), 71-75. https://doi.org/10.1043/00033219(2001)071<0071:DAEOAC $>2.0 . \mathrm{CO} ; 2$

McCann, A. L., Schneiderman, E. D., \& Hinton, R. J. (2010). E-teaching and learning preferences of dental and dental hygiene students. Journal of Dental Education, 74(1), 65-78. PMID: 20061532. Retrieved from https://pubmed.ncbi.nlm.nih.gov/20061532/

Moore, A. W. (1976). Orthodontic education: Past, present, and future. American Journal of Orthodontics, 69(1), 42-56. https://doi.org/10.1016/0002-9416(76)90097-X

O’Brien, K. (1997). Undergraduate orthodontic education: what should we teach rather than what can we teach? British Journal of Orthodontics, 24(4), 333-334. https://doi.org/10.1093/ortho/24.4.333

Olson, R. E., \& Bialocerkowski, A. (2014). Interprofessional education in allied health: a systematic review. Medical Education, 48(3), 236-246. https://doi.org/10.1111/medu.12290

Pocock, S. J. (1983). Clinical trials: a practical approach. Chichester, United Kingdom. Wiley, 125-129. https://doi.org/10.1002/bimj.4710270604

Rao, G. K. L., Iskandar, Y. H. P., \& Mokhtar, N. (2020). Understanding the nuances of Elearning in orthodontic education. Education and Information Technologies, 25, 307-328. https://doi.org/10.1007/s10639-019-09976-2

Rosenberg, H., Grad, H. A., \& Matear, D. W. (2003). The Effectiveness of Computer-Aid, SelfInstructional Programs in Dental Education: A Systematic Review of the Literature. Journal of Dental Education, 67(4), 524.

Schönwetter, D. J., Reynolds, P. A., Eaton, K. A., \& De Vries, J. (2010). Online learning in dentistry: an overview of the future direction for dental education. Journal of Oral Rehabilitation, 37, 927-940. https://doi.org/10.1111/j.1365-2842.2010.02122.x

Schönwetter, D. J., Gareau-Wilson, N., Cunha, R. S., \& Mello, I. (2016). Assessing the Impact of Voice-Over Screen-Captured Presentations Delivered Online on Dental Students' Learning. Journal of Dental Education, 80(2), 141-148.

Silva, T. R., \& Canto, G. D. (2014). Integração odontologia-fonoaudiologia: a importância da formação de equipes interdisciplinares. Revista CEFAC, 16(2), 598-603. https://doi.org/10.1590/1982-02162014222-12

Turner, P. J., \& Weerakone, S. (1993). An evaluation of a hypertext system for computerassisted learning in orthodontics. British Journal of Orthodontics, 20(2), 145-148. https://doi.org/10.1179/bjo.20.2.145 


\section{Macrothink}

Ulkur, F., Germec-Cakan, D., \& Ozdemir, F. (2015). Comparison of outcomes of recorded lecture and hands-on course education in orthodontic cast analysis. Turkish Journal of Orthodontics, 28(1), 13-18.

Will, L. A. (2015). The history of orthodontic education: A century of development and debate. American Journal of Orthodontics and Dentofacial Orthopedics, 148, 01-13. https://doi.org/10.1016/j.ajodo.2015.09.004

Zimmerman, T. D. (2012). Exploring learner to content interaction as a success factor in online courses. The International Review of Research in Open and Distributed Learning, 13(4), 152-165. https://doi.org/10.19173/irrodl.v13i4.1302

Zlatkin-Troitschanskaia, O., \& Shavelson, R. J. (2019). Advantages and challenges of performance assessment of student learning in higher education. British Journal of Educational Psychology, 89(3), 413-415. https://doi.org/10.1111/bjep.12314

\section{Copyright Disclaimer}

Copyright for this article is retained by the author(s), with first publication rights granted to the journal.

This is an open-access article distributed under the terms and conditions of the Creative Commons Attribution license (http://creativecommons.org/licenses/by/3.0/). 